\title{
Differences and Divergence in Chinese and European Thought
}

\author{
Rong Zhou' ${ }^{1}$, Bo Zhang ${ }^{2}$ \\ ${ }^{1}$ Faculty of Foreign Language Studies, Harbin University of Science and Technology, Harbin, China \\ ${ }^{2}$ Faculty of Economics and Management, Harbin University of Science and Technology, Harbin, China
}

Email address:

1401586660@qq.com (Rong Zhou),478356444@qq.com (Bo Zhang)

\section{To cite this article:}

Rong Zhou, Bo Zhang. Differences and Divergence in Chinese and European Thought. International Journal of Education, Culture and Society. Vol. 3, No. 1, 2018, pp. 14-18. doi: 10.11648/j.ijecs.20180301.14

Received: January 25, 2018; Accepted: February 9, 2018; Published: April 19, 2018

\begin{abstract}
This paper examines the obvious divergences in Chinese and European thought through cultural genes, the chronological development of Chinese thought and the origins of European thought. Chinese and European thought have different focuses- Chinese thought centers on human relations and European thought on knowledge and rationality.
\end{abstract}

Keywords: Cultural Gene, Chronological Development, Origins

\section{Introduction}

\subsection{Cultural Genes}

Developing from their ancient cultural characteristics, Asia and Europe began from the Paleolithic hunter-gatherer lifestyle, and step-by-step developed into Neolithic agricultural settlers. They had quite different paths of development. The differences between them determined their different paths of cultural development. The factors that influenced the direction of development are evident in two areas today- Different people, in different natural environments, would develop their respective behavior patterns and social structure. The idea of biological genes may be borrowed to describe cultural genes.

\subsection{Different Genes}

European cultural genes, inherited from their ancestral battle-tribes, allowed them to build enterprises, and expand unrestrained [1]. These genes differed significantly from Chinese genes that were more introverted and demonstrated stability. The ancient peoples of China and Europe took very different paths: The Chinese chose to settle in agriculture, whilst Europeans chose to continuously conquer and expand.

\section{Developments of Chinese Thoughts}

\subsection{Western Zhou Dynasty}

The feudal system that Western Zhou constructed and consequent similar systems had in fact laid the foundation of Confucianism. People were destined to only select the monarchy that benefitted them most and commissioned the king to govern the world [2]. The concept of destiny was far beyond the tribal or ethnic protectors of ancient times and the monarchy became the moral judge of society, their behavior deemed the most idealistic. The feudal system of the Zhou Dynasty encompassing the ancestral worship held by the Shang Dynasty was a step forward, gluing the moral significance of destiny and ancestral authority together.

The bronze inscription visible on the Western Zhou Dynasty was usually comprised of two aspects: one was a claim of highest morality; the other was a reflection of its ancestral lineage. Feudalism in the Zhou Dynasty became popular with the conversion of this ideal, transferring into popular general thought until the Spring and Autumn Period when Confucius lived. The feudal system and the transformation of this concept over time had become a universal ideological system until the era of Confucius.

\subsection{Confucius}

In the era of Confucius, all previous etiquette collapsed and 
the feudal system of the Western Zhou Dynasty became an empty name. In fact, various feudal lords of the domain competed for development rights and were successful; strength and resources had become decisive objectives, and the entire value system established by the feudal system of the Western Zhou Dynasty ceased to exist. From the very beginning, Confucius had not only expressed the importance of individual perfection, but also of mutual relationships based on morality.

The most important factor in the implementation of Confucianism in the world was the rules of human relations. Confucius established a thought foundation for the Chinese thousands of years ago, his movement based on a personal and social knowledge, rather than cognitive such as academic circles of today. It should be noted that this is the biggest difference between Chinese and European thinking.

He categorized four subjects for his disciples: morality, politics, language and literature. Each of these four subjects developed outstanding representatives, and the objectives of each were as follows: morality was the exercise of one's personality; politics was learning how to serve the people; language was dealing with social affairs and information communication; literature was delivering messages, like language.

Confucianism had two missions: to comfort individual people as well as the wider global community. It was concerned not only about citizens at home, but also elsewhere: the well being of all mankind. This principle had a universal and eternal value. Practitioners ambitious enough had to know how to improve and perfect themselves, to rectify their own flaws, which would then enable them to comfort others. This was the highest level of morality.

The fundamental idea of Mencius was the eternal concern over the link between human nature and God. People must be good so God would be also- obligated to protect and take care of His people.

\subsection{Post-Confucius}

Post-Confucianism prepared people to self-cultivate, regulate their family, and govern their country as well as the world[3]. Step by step, they intended to improve their inner quality, which in turn would qualify them to participate in the promotion of their population's well being at all levels.

Monists likely formed from the Confucians, they emphasized the absolute goodness of God and the people's admiration for him. This intention was originally good, but finally became a hierarchy of obedience to authority. The highest authority was God, and the emperor worshipped him, as well as did the oracle. Monists in order to attempt to be good had inevitably denied any personal autonomy and individuality. Yang Zhu advocated the independence of personality and claimed Monists were actually on the extreme side of Confucianism, which had caused concern amongst other Confucians.

The Mencius era was in a period of war during which time Confucians held the tenet that whatever ambition a person had, not only should he perfect himself, but he should care for other people as well. Goodness was the first objective of inner quality. Among the four subjects, morality and politics played vital roles and the final objective was directing individuals or groups into goodness. Mencius believed that human nature was good, but due to the temptation of desire a person may lose the goodness that originated in his nature. Thus, Confucianism began to possess a binary division.

The Xunzi era was in the late War Period. Xunzi claimed that human goodness was "fake", which did not mean pretend or deceitful, but referred to the level of human effort involved in maintaining it. Human nature could be good, but could become evil when lead into temptation if not cautious. One had to strive to develop a good direction in their life in order to be good. Mencius and Xunzi developed two divisions of good and evil, both of which could transform and evolve between one another.

The so-called Legalist theory originated from Xunzi, one of whose principle disciples was Han Fei, who integrated his many practical political experiences into management science and developed the theory of politics; a further disciple of whose was $\mathrm{Li} \mathrm{Si}$, who became assistant to the first emperor of the Qin Dynasty, and began planning an administrative system. Political affairs, one of the four subjects of Confucianism, had finally developed into a political theory and practice. Confucianism in the next thousand years, alongside the emperor system, became the main theoretical foundation of the civil service system.

\subsection{Daoism}

The real rival of Confucianism was Taoism, founded by Lao Tzu and Chuang Tzu, who both lived in the Chu kingdom in the Huai Han area, in which there were many hills, lakes, streams and forests: A completely different landscape from the northern plain and loess. The southern Legend system of Chu culture also contrasted from the different features of the northern system.

Various Gods are said to have dwelt in the mountains of the Southern waterside including handsome male gods, graceful goddesses and many cute holy spirits who were the main inspiration behind many fairy tales. Compared with the people in the north, for whom it was difficult to live, where they had to be reserved and self-disciplined and respect the boundaries between themselves and others; it was easy for the people in the South who had space to express themselves. Southerners were lively and free, had more self-esteem and more respect for one another, and were compatible with nature, rather than confrontational. Thus, under such circumstances more focus was placed on respecting individuality and personality, and even abandoning the collective, unwilling to have a strong collective obstruction of personal freedom. They also advocated to not push "naturalism" into absoluteness.

As noumenon, Lao thought that the universe was in chaos, with everything flowing. Chuang Tzu believed that if the angles and scales of measurement and judgment were different the results would be different. In addition to theories of absolute truth, both Lao's nihilism and Chuang Tzu's theory of relativity put forward some other choices, but also negated 
any notions of arbitrary thinking.

\subsection{Fusion of Confucius, Daoism and Buddhism}

The rules of governing states provided by Confucianism, together with the emperor system, followed by the concept of destiny from Zhou Dynasty, became the legal basis for state power. The most important factor of this combination was the inspection system of Han Dynasty.

Induction theory by Dong Zhongshu was a gigantic multi-level system, the biggest layer of which covered the whole verse; the second layer covered the world, below that, nations were sub-layer, and community and neighborhood yet another hierarchy, even the viscera and organs within an individual's body were one layer. Individuals had a certain place in each layer above [4].

From the layer of the human body to the layer of the universe, each ran through upper and lower levels. The various departments of each layer were mutually effected and balanced, and could not be too many or too few. Only if the power of each department matched, could it achieve the best balance. Interaction between similar layers also existed. Thus, in this huge system, a person could not escape from between heaven and earth, he was only a small point between the layers of the universe, but this small point might also effect the operation of the universe as a whole.

Dong Zhongshu's metaphysical theory system had some similarities to present-day scientific theories of universal structure, physical and chemical structure, biological cell structure, human relationship analysis in society, as well as modern scientific cosmology.

The Confucian system constructed by Dong Zhongshu penetrated Chinese culture and influenced Chinese thought over the past two thousand years. His theory acted as a civil servant, holding Confucian moral courage, having a conscious sense of purpose, and devoting itself to the state.

The so-called outer-Confucian inner-law was namely Confucianism as the outer decoration of its absolute legalist interior. At the social level, through the inspection system, civil service systems also had a mechanism of self-procreation and self-renewal. This kind of self-perfection enabled balance between social elite groups. As a whole, it had enough power to compete with Imperial power, both becoming interdependent and balanced. The Confucian scholars were not priests, but had the same function as such. They were the spokesmen of authoritative ideology and extensions of the authoritative system.

After the Eastern Han Dynasty, Buddhism came to China. There was considerable similarity and compatibility between the system of Buddhism and Taoism- Taoism's out-of-the-world thinking and Confucianism's into-the-world thinking formed a compatible dialectical relationship. A knowledgeable Chinese person, at a young or middle age, should be positive when addressing matters; whilst at an older age, he should be content in attempting less than he would at a younger age.

Confucianism, Taoism and Buddhism, fused together and affected everyone in Chinese culture. This was the true spirit of Chinese culture. Ups and downs in the Dynasties of China continued to change their masters. The social structure in China also underwent great changes. However, Confucianism, Buddhism and Taoism long dominated Chinese thought.

\section{Developments of European Thoughts}

\subsection{Complexity}

The origin of traditional western thought is quite complex [5], and includes at least three different sources: Mesopotamian, Egyptian and Jewish. Every local culture had its own ideological form, which then integrated into western tradition. The main integration of the time was when Christianity entered the mainstream of the Roman Empire. Compared to the traditional complex Western system, the Western Zhou Dynasty integrated into China at approximately the end of the Spring-Autumn and War Kingdom eras.

Firstly, in Mesopotamian culture, there were many contrasts: an alpine desert with wet mountains, dry and wet weather, sweet and brackish water, herdsmen and farmers. The contrast also appeared in many of their myths, and finally came down to the confrontation between God and the Devil.

God and the Devil were the main problems of European ideas and such bi-divisional thinking was not the same as Chinese bi-complementary and bi-evolutional thinking. A knife was cut into two halves, conflicting with each other, without the possibility of fusion. The two antagonistic mentalities have long existed in Western thought and this contrast of positive and negative dialectics has evolved and thoroughly integrated into modern culture.

Egypt, secluded and compact in the Nile Valley, developed into a unique civilization. The image of their God was a warrior: half man and half beast. In this multi-God culture system, the Egyptian political chief - Pharaoh, was the direct incarnation of God. In $14^{\text {th }}-15^{\text {th }}$ century BC, (equivalent to the Chinese Shang Period), Pharaoh Eh Natron believed the sun to be the Great God 'Aton' and he was the only true God of all.

This mono-god faith excluded the original multi-god belief and Pharaoh Eh Natron incurred opposition from the polytheistic priests. He was exiled, and his singular-god faith was overthrown, but the idea survived in the world and was absorbed by the leader of the ancient Israelites, Moses[6].

Moses took twelve tribes from Egypt and wandered in the desert for 40 years during which time Moses composed the Ten Commandments, which became a core belief of his monotheistic faith. He, as a national protector of Israel, established a national single-god faith for the Jewish people.

\subsection{Christianity}

At the height of the Roman Empire, Jesus, based on his Jewish faith, created a new religion: Christianity. After three generations of accumulation and development by Jesus, Peter and Paul, the Christian doctrine was no longer confined to the idea that God only chose Israelites as His people and instead selected those who respected Him, who then became his followers[7]. As a result, Christianity, originating from Judaism, became a form of ethno-religion upholding the 
universal belief that all people who believed in God were God's disciples.

The ideology of good against evil that developed from Mesopotamia evolved to take the form of an eternal battle where evil challenged good and that good fought against it. This idea was eventually absorbed by Christianity and integrated into the Christian doctrine.

In Mesopotamian mythology, a Spring maiden was imprisoned in a dark cave, so the earth froze over and nothing could grow. Her lover saved her and gave vitality back to the earth, risking his life to do so. In the mythology of the battle between God and the Devil, a young captain named Mark Duke, recognized for his bravery and sacrifice in charging into the enemy ranks became the God of Babylon, representing resurrection and redemption. This theme was later reprised with Jesus Christ sacrificing himself to save people from death, receiving eternal life after his resurrection.

It is said that ancient Greek culture might be one of the most important sources of European culture. At the height of ancient Greek culture, chronologically paralleled in the Spring/Autumn period in China, a number of intellectuals provided important ingredients for the future of Western culture. Pythagoras and his colleagues believed that universal numbers were the biggest secret of the universe. He developed the cognitive basis for seeking knowledge in western thinking and devised intellectual methodologies of discovering the ontology of the universe.

\subsection{Contrast Between Ancient Greek Thoughts and Ancient Chinese Thoughts}

The concern of the Chinese people was to arrange peace in the world, and its corresponding social order was to provide human welfare. That is to say that what the Chinese people were looking for was the relationship among people and that discovering it could provide a categorization of ethics[8]. The Greek tradition under the influence of Socrates was to search for knowledge and to build a methodology for doing so. Socrates, Plato, and Aristotle- three generations of masters, developed this thought-form, which became part of mainstream Western thought.

The Stoics, in essence, were quite similar to advocates of Chinese Confucianism in that they developed the ability to control their desires and correct their behavior, achieving real peace of mind and comfort. At the same time, they had a certain responsibility for society, to serve the community. The national spirit of the ancient Roman Empire had similarities to that of the Stoics.

The Epicureanism was a school of thought close to the ancient Chinese theory of Yang Zhu. They valued people individually and pursued happiness not to satisfy materialistic desires, or to indulge in lust, but for physical and mental tranquility. They also opposed superstitions, not believing in a God-dominated life.

Thirdly, the Skeptics, quite like Chinese Taoist thinkers, believed that people could not really pursue or attain real knowledge.

After the rise of Christianity, although Jesus had clearly defined its position, Paul had played an important role in defining Christianity as a global religion by establishing supporters outside of Israel, which would become one of the faith's universal gospels. Not only did he make Christianity transcend ethnic groups, but he also added Greek ideas into Christian doctrines. The Stoic doctrine focused on the cultivation of personal character and self-discipline became a constriction of Christianity. At the same time, the notion of redemption originating from Mesopotamia, matched with Moses' Ten Commandments [9].

Paul and Peter absorbed many religious ideas from Mesopotamia, Egypt and Persia, advocating that only believing in God could grant an eternal life, and finally completing the main structure of Christianity. From the various cultural sources of ancient times, Western civilization was built into a complete system after the emperor Constantine decreed Christianity as the national religion.

\section{Conclusion}

Chinese culture was concerned with the order of the world and the meaning of life in it, whilst European culture was concerned with thinking beyond nature and the human mind. The dualism of Chinese thought, and the coexistence of multiple concepts, allowed a dialectical evolution to occur, broadening the spectrum of available thought, while the binary-opposition of European thought became a conflict of binary differentiation, which lacked the room for compromise [10].

The obvious difference between Chinese and European thought was that the Chinese cared about the order of people in society whilst Europeans were concerned with nature; the Chinese mentality was to pursue harmony in the universe, while the European mentality was to obtain victory from confrontation.

\section{References}

[1] $\mathrm{Xu}$ Daoyun, Contrast between Chinese and Western Civilization. [M]. Zhejiang people's Publishing Press, 2016

[2] Zhou Huiming, Weng Hansong. Thinkers. Beijing: Life, Readers and New Knowledge. [M]. Joint Publishing Company, 1992

[3] Xu Hui. Body Politics in Chinese History. [M]. Beijing: The Commercial Press, 2013

[4] Laff Detel. German History. [M]. Munich Max Hueber Press, 1987

[5] Liang Qichao. Academic History in Qing Dynasty. [M]. Chinese People's University Press, 2004

[6] Chang Yaoxin. Greek and Roman Mythology. [M]. Foreign Teaching and Research Press, 1981

[7] Wang Sifan. The Core Secret in Historical Crucial Moment. [M]. Dunhuang Arts Press, 1999

[8] Roger E. Backhouse. The Penguin History of Economics. Penguin Group, 2002 
[9] Maryanna K. D., Joanna, K, Edward, N. Karl. An Introduction to American Culture prentice Hall Regents, 1990

\section{Biography}

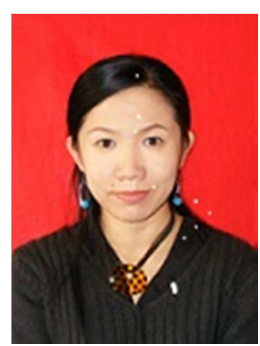

Rong Zhou (b.1972) is an associate professor at Harbin University of Science and Technology. Publications include "Cognition and metaphor of English emotion formulaic sequence" (2015). The paper is one part of a 2015 project (Evaluation research on Wernicke aphasiac language treatment in the process of language rehabilitation, and the project number is $15 \mathrm{YYB} 05$. It is also one part of 2016 National Education Ministry Project (The tracking study on the rehabilitation status of aphasia chunk ability from the linguistic prospective), and the project number is 16YJA740049.
[10] Barry Tomalin, Susan Stempeski. Cultural Awareness. [M]. Oxford Press and Chinese Eastern Normal University, 1998

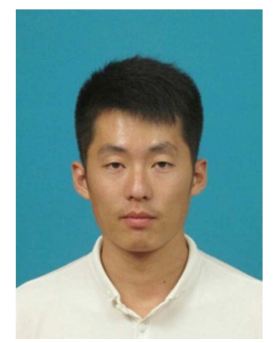

Bo Zhang (b.1993) is a postgraduate at Harbin University of Science and Technology, China. 